\title{
THE EFFECT OF COATING MATERIAL ON THE COLOR STABILITY OF GLASS-IONOMER-BASED RESTORATIVE MATERIALS: AN IN-VITRO STUDY
}

\begin{abstract}
Objectives: The aim of this study was to determine the effect of coating on the color stability of different glass ionomer cements (GICs) after immersed in different children beverages.
\end{abstract}

Materials and Methods: Four different GIC and a glass-ionomer coating material were used in this study. Disc shaped sixteen specimens of each GICs were done and divided into two groups, uncoated and coated $(n=8)$. For color change, the specimens were immersed 7 day in the four solutions of cola, orange juice, chocolate milk and water. The color measurements were carried out before immersed solutions and at the end of the 1 st and 7 th days, using a spectrophotometer. The color change $\Delta \mathrm{E}_{00}$ was calculated using the CIEDE2000 formula. Data were analyzed by Kruskall-Wallis and Wilcoxon test $(\mathrm{p}<0.05)$.

Results: The $\Delta \mathrm{E}_{00}$ values for all coated and uncoated GICs showed an increase in all solutions after 7 days of immersion. All the $\Delta \mathrm{E}_{00}$ values obtained from all the specimens immersed in cola were higher than the acceptability threshold. There was no statistical difference in terms of $\Delta \mathrm{E}_{00}$ values between the coated and uncoated specimens of the same GICs at same time periods.

Conclusions: Coating of GICs exhibited relatively good color stability and protect from the discoloration. The staining effect of GICs should be carefully considered when selecting dental materials in pediatric dentistry.

Keywords: Surface coating agent, glass-ionomer cement, staining.
Burak Çarıkçıŏlu ${ }^{1}$

ORCID IDs of the authors:

B.Ç. $\quad$ 0000-0001-5951-8179

\footnotetext{
${ }^{1}$ Department of Pediatric Dentistry, Faculty of Dentistry, Çanakkale Onsekiz Mart University, Çanakkale, Turkey.
}

$\begin{array}{ll}\text { Received } & : 29.09 .2021 \\ \text { Accepted } & : 11.12 .2021\end{array}$

How to Cite Çarıkçıŏlu B. The Effect of Coating Material on the Color Stability of Glass-Ionomer-Based Restorative Materials: An In-Vitro Study. Cumhuriyet Dent J 2021;24:4:386-394.

*Corresponding Author:

Department of Pediatric Dentistry, Faculty of Dentistry, Çanakkale Onsekiz Mart University, Çanakkale, Turkey.

Phone: + 902862633533 


\section{INTRODUCTION}

The glass ionomer cements (GICs), compomers, and composites are commonly used restorative materials in the paediatric dentistry. ${ }^{1,2}$ Besides the treatment necessities, these dental materials are also preferred for their esthetics. ${ }^{3}$ Their esthetically pleasing results, anti-cariogenic potentials depending on flouride release, biocompatibilities, and chemical bonding to dental tissues made GICs a more qualified material group when compared to other restorative materials. ${ }^{4}$ Besides that, GICs also have weak physical and chemical characteristics such as sensitivity to dehydration and moisture contamination during initial hardening reaction, a prolonged setting reaction time, and a rough surface texture. ${ }^{5}$ In order to overcome these disadvantages, enhance handling characteristics, increase working times, and improve esthetic properties, materials such as high-viscosity GIC (HVGIC), resin-modified GIC (RMGIC), and reinforced GIC (RFGIC) were developed by changing the formulations of several GIC-based restorative materials. ${ }^{1,6}$

In order to achieve the ideal esthetic, the restorative materials should be able to mimic the tooth in terms of color, translucency, and surface texture and they should exhibit long term color stability. ${ }^{7}$ The discoloration of restorative materials are explained with absorption and adsorption mechanisms of staining agents due to intrinsic and extrinsic factors. ${ }^{8}$ The intrinsic discolorations are described as the discoloration of restorative material arising from the oxidation between resin matrix and filler components. ${ }^{9}$ The exogenous discoloration however, depends on the type of staining particles, the surface roughness, the type of restorative material, and staining solution exposure time. ${ }^{10}$ Exogenous discoloration occurs generally as a result of the consumption of colored beverages. ${ }^{8}$

In order to prevent the possible negative results in physical features due to liquid contamination, manufacturer's recommend the use of GICs together with surface coating resin. It was reported that the applying coating resin to the GICs gives the material gloss, prevents the decrease in the translucence of material in the course of time, provides a smooth surface by filling the gaps arising from material and finishing process, decreases the moisture sensitivity in the short term, increases the fracture and wear resistance of restoration and improves the structural properties of the material. ${ }^{11}$ The effects of coating resin on the mechanical properties of GICs have been previously reported ${ }^{12-14}$ but the studies on the effect of coating resin application on the coloration mainly remained limited to the composite resins. ${ }^{15-17}$

This study aimed to evaluation of the color stability of coated and uncoated 4 different GICbased restorative materials after immersed in various staining solutions. The null hypotheses were (1) GIC type has no effect on color stability; (2) different staining solutions and immersion period would not show significant difference on the color stability; (3) coating of GICs would not change the staining susceptibility.

\section{MATERIALS AND METHODS}

This study was designed as an in vitro research. The types and contents of dental restorative materials used in the present study are presented in Table 1 and the details of solutions in Table 2.

Table 1: Description of the materials.

\begin{tabular}{|c|c|c|c|c|}
\hline Material (Code) & Manufacturer & Type & Composition & Batch Number \\
\hline $\begin{array}{l}\text { Riva Light Cure } \\
(\text { RLC) }\end{array}$ & $\begin{array}{l}\text { SDI, Victoria, } \\
\text { Australia }\end{array}$ & RMGIC & $\begin{array}{l}\text { Fluoro-aluminosilicate glass/ } \\
\text { Polyacrylic acid Aluminium- } \\
\text { fluoro-silicate }\end{array}$ & K1111265EG \\
\hline $\begin{array}{l}\text { Chemfil Rock } \\
\text { (CR) }\end{array}$ & $\begin{array}{l}\text { Dentsply, DeTrey, } \\
\text { Konstanz, } \\
\text { Germany }\end{array}$ & Zinc RFGIC & $\begin{array}{l}\text { Calcium-aluminium-zinc- } \\
\text { fluorophosphor silicate glass, iron } \\
\text { oxide pigments, titanium dioxide } \\
\text { pigments/Polycarboxylic Acid, } \\
\text { water, tartaric Acid }\end{array}$ & 1903000819 \\
\hline
\end{tabular}




\begin{tabular}{|c|c|c|c|c|}
\hline $\begin{array}{l}\text { Riva Self Cure } \\
\mathrm{HV}(\mathrm{RSC})\end{array}$ & $\begin{array}{l}\text { SDI, Victoria, } \\
\text { Australia }\end{array}$ & GIC & $\begin{array}{l}\text { Fluoro-aluminosilicate glass/ } \\
\text { Polyacrylic acid/Tartaric acid }\end{array}$ & C1114854F \\
\hline Zirconomer (Z) & $\begin{array}{l}\text { SHOFU Inc, } \\
\text { Kyoto, Japan }\end{array}$ & $\begin{array}{l}\text { Zirconia } \\
\text { RFGIC }\end{array}$ & $\begin{array}{l}\text { Alumino-fluoro-silicate glass, } \\
\text { zirconium oxide/Polyacrylic } \\
\text { acid, deionized water, tartaric } \\
\text { acid }\end{array}$ & 07183080 \\
\hline Riva Coat & $\begin{array}{l}\text { SDI, Victoria, } \\
\text { Australia }\end{array}$ & $\begin{array}{l}\text { Light-cured } \\
\text { resin coating }\end{array}$ & Acrylic monomer & 190107 \\
\hline
\end{tabular}

Table 2: Immersion solutions used in the study.

\begin{tabular}{lccc}
\hline Product & Material type & Manufacturer & pH \\
\hline Cola & Soft drink & The Coca-Cola Co., & 2.5 \\
Orange juice & Fruit juice & Istanbul, Turkey & 3.9 \\
Chocolate milk & Milk & Danos, Istanbul, Turkey & 6.6 \\
Distilled water & Water & Polifarma, Tekirdağ, & 6.4 \\
\hline
\end{tabular}

\section{Specimen Preparation}

Specimens were made following the manufacturers' directions, placed into teflon moulds (2mm-thickness and 5mm-diameter) and held between glass slabs with polyester-mylar strip onto both sides under finger pressure to form a smooth surface. The specimens in the Chemfil Rock, Riva Self Cure and Zirconomer group were kept in the mold during the initial cement setting. Only the specimens in the Riva Light Cure group were polymerized from each surface according to the manufacturer's directions with a LED polymerization light (Elipar Freelight 2, 3M ESPE, Germany, $1.200 \mathrm{~mW} / \mathrm{cm}^{2}$ ). Polymerization device was tested by a radiometer (Hilux UltraPlus, Benlioglu Dental, Ankara, Turkey). All specimens were taken out from the mold and a total of 256 specimens (64 from each GIC group) were prepared. A caliper was used to measure the final thickness of the specimens (UltraCal V, Fowler, Sylvac, Swiss $)(2 \pm 0.1 \mathrm{~mm})$. Each different GIC specimens were divided randomly into two subgroups as 32-coated and 32-uncoated specimens. Thirty-two of the specimens prepared using the same GIC were coated with Riva Coat according to manufacturers' directions using the same LED light curing device. Before color measurement the specimens were immersed in distilled water for 24 hours at $37^{\circ} \mathrm{C} .^{18}$

\section{Discoloration measurements and immersion cycles}

The spectrophotometer (VitaEasyshade V, Vita Zahnfabrik, Bad Sackingen, Germany) used in the present study and calibrated before every color measurement. The color measurements of specimens were performed on standard neutral gray background (Munsell N7 neutral gray color) by the same operator (BÇ) with D65 illuminant light. After drying the specimens using a tissue paper, the measurements were repeated 3 times on the same surface of each specimen and the mean $\mathrm{L}^{*}, \mathrm{a}^{*}$, and $\mathrm{b}^{*}$ values were measured. The initial color measurement values $\left(L_{0}, a_{0}, b_{0}\right)$ were obtained from specimens immersed in distilled water at $37^{\circ} \mathrm{C}$ for 24 hours. The coated and uncoated specimens were randomly divided into 4 groups $(\mathrm{n}=8)$ and immersed in 4 different solutions (cola, orange juice, chocolate milk, water) then incubated in an airproof and dark environment at $37^{\circ} \mathrm{C}$. The immersion solutions were refreshed every day during the 7-day test period. The color measurements were repeated on the $1^{\text {st }}$ and $7^{\text {th }}$ days as explained before.

The color change values were obtained at the end of the $1^{\text {st }}$ and $7^{\text {th }}$ days by using CIEDE2000 formula and recorded for assessment periods $t 1$ $\left(0^{\text {th }}-1^{\text {st }}\right.$ day $)$ and $\mathrm{t} 2\left(1^{\text {st }}-7^{\text {th }}\right.$ day $)$, respectively. The formula used is below: 
$\Delta E_{00}=\left[\left(\frac{\Delta L^{\prime}}{K_{\mathrm{L}} S_{\mathrm{L}}}\right)^{2}+\left(\frac{\Delta C^{\prime}}{K_{\mathrm{C}} S_{\mathrm{C}}}\right)^{2}+\left(\frac{\Delta H^{\prime}}{K_{\mathrm{H}} S_{\mathrm{H}}}\right)^{2}+\mathrm{R}_{\mathrm{T}}\left(\frac{\Delta C^{\prime}}{K_{\mathrm{C}} S_{\mathrm{C}}}\right)\left(\frac{\Delta H^{\prime}}{K_{\mathrm{H}} S_{\mathrm{H}}}\right)\right]^{\frac{1}{2}}$

$\Delta L^{\prime}, \Delta C^{\prime}$ and $\Delta H^{\prime}$ in the CIEDE formula represent the differences in parameters lightness, chroma, and hue, respectively. $S_{L}, S_{C}$, and $S_{H}$ are the weighting functions for the $\mathrm{L}^{*}, \mathrm{a}^{*}$ and $\mathrm{b}^{*}$ coordinates, respectively. The parametric factors $\left(K_{L}, K_{C}\right.$ and $\left.K_{H}\right)$ for changes in experimental conditions were set to $1: 1: 1$. And finally, the interaction between chroma and hue differences in the blue region is accounted for by $R_{T}$ (a rotation function). ${ }^{19}$ According to CIEDE2000, the threshold values for perceptibility and acceptability were set as 0.8 and 1.8, respectively. $^{20}$

\section{Statistical Analysis}

Data were analysed using the statistical package of the SPSS for Windows, Version 19.0 (IBM, Chicago, IL, USA). Comparison between GICs color stabilities by the solutions was performed using Kruskal-Wallis test and paired comparisons were performed using Dunn-Bonferroni test. The comparisons between assessment periods for each group were performed using Wilcoxon test. pvalues $<0.05$ was considered significant.

\section{RESULTS}

$\Delta \mathrm{E}_{00}$ values of the GICs after immersed in various beverages are presented in Table 3. Cola was the solution that stained RLC and RLC+ at the highest level in $\mathrm{t} 1$ and $\mathrm{t} 2$. Moreover, the chocolate milk stained RLC + in $\mathrm{t} 2$ at the highest level. Cola and chocolate milk stained $\mathrm{CR}$ in $\mathrm{t} 1$ at the highest level, whereas cola colored it at the highest level in $\mathrm{t} 2$. Different solutions had no significant effect on the color change of $\mathrm{CR}+$ in $\mathrm{t} 1$ and $\mathrm{t} 2$. Cola was the solution stained RSC in $\mathrm{t} 1$ and $\mathrm{t} 2$ at the highest level. Chocolate milk stained RSC + at the highest level in $\mathrm{t} 2$, whereas cola was the solution stained in $\mathrm{t} 1$ at the highest level. Chocolate milk stained $\mathrm{Z}$ at the highest level in $\mathrm{t} 1$ and orange juice was the solution stained in $\mathrm{t} 2$ at the highest level. Different solutions had no significant effect on the color change of $\mathrm{Z}+$ in $\mathrm{t} 1$ and $\mathrm{t} 2$ (Table 3).

Table 3: Minimum-maximum (median) of color change values $\left(\Delta \mathrm{E}_{00}\right)$ of glass ionomer-based restorative materials (GICs) after immersion in different solutions in same time interval.

\begin{tabular}{|c|c|c|c|c|c|c|}
\hline \multirow[b]{2}{*}{ Materials } & \multirow[b]{2}{*}{$\begin{array}{c}\text { Immersion } \\
\text { period }\end{array}$} & \multicolumn{4}{|c|}{ Staining Solutions } & \multirow[b]{2}{*}{ p value } \\
\hline & & Cola & $\begin{array}{c}\text { Orange } \\
\text { juice } \\
\end{array}$ & $\begin{array}{c}\text { Chocolate } \\
\text { milk }\end{array}$ & Water & \\
\hline \multirow{4}{*}{ Riva Light Cure } & & $5.7-15.9$ & $1-6.8$ & $1.4-5$ & $1.2-3$ & \\
\hline & tI & $(11.3)^{\mathbf{A}}$ & $(3.3)^{\mathbf{B}}$ & $(2.4)^{\mathbf{B}}$ & $(2.7)^{\mathbf{B}}$ & $<0.001$ \\
\hline & & $3.2-11.5$ & $0.6-4.9$ & $0.7-2.8$ & $0.6-2$ & \\
\hline & t2 & $(10.3)^{\mathbf{A}}$ & $(2.3)^{\mathbf{B}}$ & $(1.5)^{\mathbf{B}}$ & $(1)^{\mathbf{B}}$ & $<0.001$ \\
\hline \multirow[b]{2}{*}{ Riva Light } & & $1.8-8.6$ & $0.3-5.2$ & $0.9-5.1$ & $1.5-2.5$ & \\
\hline & t1 & $(5.1)^{\mathbf{A}}$ & $(2.4)^{\mathbf{A B}}$ & $(1.8)^{\mathbf{B}}$ & $(2.2)^{\mathbf{A B}}$ & 0.023 \\
\hline \multirow[t]{2}{*}{ Cure+ } & & $5.1-13.5$ & $1.3-2.7$ & $7.5-11.6$ & $1.2-2.2$ & \\
\hline & $\mathrm{t} 2$ & $(8.1)^{\mathbf{A}}$ & $(2)^{\mathbf{B}}$ & $(10.4)^{\mathbf{A}}$ & $(1.3)^{\mathbf{B}}$ & $<0.001$ \\
\hline \multirow{4}{*}{ Chemfil Rock } & 4 & $1.2-6.5$ & $0.9-3.9$ & $1-5.6$ & $0.2-1.2$ & \\
\hline & t1 & $(2)^{\mathbf{A}}$ & $(1.5)^{\mathbf{A B}}$ & $(1.4)^{\mathbf{A}}$ & $(0.7)^{\mathbf{B}}$ & 0.002 \\
\hline & & $1.2-7$ & $1.2-3.7$ & $0.3-3.1$ & $1.1-2.3$ & \\
\hline & $\mathrm{t} 2$ & $(2.5)^{\mathbf{A}}$ & $(2.1)^{\mathbf{A B}}$ & $(0.8)^{\mathbf{B}}$ & $(1.8)^{\mathbf{A B}}$ & 0.021 \\
\hline \multirow{4}{*}{ Chemfil Rock+ } & & $0.3-4.1$ & $0.4-6.8$ & $0.4-5$ & $0.2-1.3$ & \\
\hline & t1 & $(2.6)$ & $(2)$ & $(2.3)$ & $(0.8)$ & 0.73 \\
\hline & & $0.6-8.3$ & $0.5-6.3$ & $0.5-4.9$ & $1.2-1.5$ & \\
\hline & $\mathrm{t} 2$ & $(2.9)$ & $(1.7)$ & $(0.8)$ & $(1.3)$ & 0.102 \\
\hline \multirow{4}{*}{ Riva Self Cure } & & $1.6-4.7$ & $0.7-4.5$ & $0.4-4.3$ & $1-2$ & 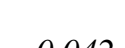 \\
\hline & tI & $(2.3)^{\mathbf{A}}$ & $(0.9)^{\mathbf{B}}$ & $(2.5)^{\mathbf{A B}}$ & $(1.2)^{\mathbf{A B}}$ & 0.042 \\
\hline & & $4.5-46.4$ & $0.9-4.1$ & $0.1-1.8$ & $0.5-1.8$ & \\
\hline & $\mathrm{t} 2$ & $(22.7)^{\mathbf{A}}$ & $(1.6)^{\mathbf{A B}}$ & $(0.6)^{\mathbf{B}}$ & $(1.3)^{\mathbf{B}}$ & $<0.001$ \\
\hline \multirow[t]{2}{*}{ Riva Self Cure+ } & t1 & $0.6-7$ & $0.5-7.3$ & $0.7-3.1$ & $0.2-1$ & 0.002 \\
\hline & & & 389 & & & \\
\hline
\end{tabular}




\begin{tabular}{|c|c|c|c|c|c|c|}
\hline & & $(2.8)^{\mathbf{A}}$ & $(1.2)^{\mathbf{A B}}$ & $(1.9)^{\mathbf{A}}$ & $(0.5)^{\mathbf{B}}$ & \\
\hline & $\mathbf{t} 2$ & $\begin{array}{l}1-13.3 \\
(4)^{\mathbf{A B}}\end{array}$ & $\begin{array}{l}0.5-4 \\
(1.2)^{\mathbf{B}}\end{array}$ & $\begin{array}{c}6.2-11.2 \\
(8.6)^{\mathrm{A}}\end{array}$ & $\begin{array}{c}1.1-1.8 \\
(1.5)^{\mathbf{B}}\end{array}$ & $<0.001$ \\
\hline \multirow{2}{*}{ Zirconomer } & t1 & $\begin{array}{c}0.5-35.3 \\
(5.6)^{\mathbf{A B}}\end{array}$ & $\begin{array}{c}1.4-15.8 \\
(9)^{\mathbf{A B}}\end{array}$ & $\begin{array}{c}4.6-35.1 \\
(12)^{\mathbf{A}}\end{array}$ & $\begin{array}{c}1.1-2.4 \\
(1.9)^{\mathbf{B}}\end{array}$ & 0.006 \\
\hline & $\mathbf{t} 2$ & $\begin{array}{c}1.1-23.8 \\
(2.6)^{\mathbf{A B}}\end{array}$ & $\begin{array}{c}2.6-19.8 \\
(12.4)^{\mathbf{A}}\end{array}$ & $\begin{array}{c}1-34.5 \\
(5)^{\mathrm{AB}}\end{array}$ & $\begin{array}{c}1.2-2.4 \\
(1.7)^{\mathbf{B}}\end{array}$ & 0.017 \\
\hline \multirow{2}{*}{ Zirconomer+ } & t1 & $\begin{array}{c}1.4-5.8 \\
(3.2)\end{array}$ & $\begin{array}{c}0.7-4.2 \\
(1.8)\end{array}$ & $\begin{array}{c}1.7-5.1 \\
(2.1)\end{array}$ & $\begin{array}{l}3.3-4 \\
(3.7)\end{array}$ & 0.194 \\
\hline & t2 & $\begin{array}{l}1-7.5 \\
(3.2) \\
\end{array}$ & $\begin{array}{c}0.5-7.1 \\
(2.3) \\
\end{array}$ & $\begin{array}{c}0.6-3.4 \\
(1.4) \\
\end{array}$ & $\begin{array}{c}1.2-2.3 \\
(2)\end{array}$ & 0.269 \\
\hline
\end{tabular}

+: refers to the specimens coated with Riva Coat

Different uppercase letters $(A, B)$ indicate statistically significant differences (in a row) ( $p<0.05)$

All the $\Delta \mathrm{E}_{00}$ values obtained from all the specimens immersed in cola were higher than the acceptability threshold $\left(\Delta \mathrm{E}_{00}=1.8\right)$. The immersion solutions did not show any significant color change in the $\mathrm{CR}+$ and $\mathrm{Z}+$ at any time period (Table 3).

The $\Delta \mathrm{E}_{00}$ values of GICs used in the present study in different immersion periods are presented in Table 4. In both periods, the group showing the highest $\Delta \mathrm{E}_{00}$ value was $\mathrm{Z}$, the coating in this group slightly reduced the discoloration but yielded no significant difference. RSC+ group showed the minimum discoloration in t1 but $\Delta \mathrm{E}_{00}$ values significantly increased after the $1^{\text {st }}$ day $(p<0.001)$. There was no statistical differences with regard to $\Delta \mathrm{E}_{00}$ values between coated and uncoated specimens of the same GICs evaluated between themselves at same time periods.

Table 4: Minimum-maximum (median) of color change values $\left(\Delta \mathrm{E}_{00}\right)$ of glass ionomer-based restorative materials (GICs) after different immersion periods.

\begin{tabular}{|c|c|c|c|}
\hline \multirow{2}{*}{ Materials } & \multicolumn{2}{|c|}{ Immersion Period } & \multirow[b]{2}{*}{$* p$} \\
\hline & t1 & $\mathbf{t} 2$ & \\
\hline Riva Light Cure & $1-15.9(3.1)^{\mathrm{a}}$ & $0.6-11.5(1.7)^{\mathbf{a b}}$ & 0.001 \\
\hline Riva Light Cure + & $0.3-8.6(2.3)^{\mathrm{abc}}$ & $1.2-13.5(3.9)^{\mathrm{a}}$ & 0.006 \\
\hline Chemfil Rock & $0.2-6.5(1.3)^{\mathbf{b c}}$ & $0.3-6.9(1.9)^{\mathbf{a b}}$ & 0.568 \\
\hline Chemfil Rock + & $0.2-6.8(1.6)^{\mathbf{b c}}$ & $0.5-8.3(1.3)^{\mathbf{b}}$ & 0.866 \\
\hline Riva Self Cure & $0.4-4.7(1.7)^{\mathbf{b c}}$ & $0.1-46.4(1.5)^{\mathbf{a b}}$ & 0.272 \\
\hline Riva Self Cure + & $0.2-7.3(1.2)^{\mathbf{c}}$ & $0.5-13.3(3.1)^{\mathbf{a b}}$ & $<0.001$ \\
\hline Zirconomer & $0.5-35.3(5.3)^{\mathrm{a}}$ & $1-34.5(2.8)^{\mathrm{a}}$ & 0.080 \\
\hline Zirconomer + & $0.7-5.8(3.4)^{\mathbf{a b}}$ & $0.5-7.5(2)^{\mathbf{a b}}$ & 0.084 \\
\hline$* * p$ & $<0.001$ & $<0.001$ & \\
\hline
\end{tabular}

+: refers to the specimens coated with Riva Coat

*Wilcoxon Signed Rank Test, **Kruskall Wallis Test ( $p<0.05)$

Different lowercase letters ( $a, b, c)$ indicate statistically significant differences (in a column)

\section{DISCUSSION}

This study, color stability of four different GICbased restorative materials, on which a surface coating was applied or not, after exposure to different immersion solutions was investigated. According to the results obtained, it was found that type of restorative material, type of staining solution, and immersion time had effect on the color stability of GICs; thus, the first two hypotheses have been rejected and the third partially accepted.

In addition to all the positive features of GICs, they are often preferred as a restorative material in paediatric dentistry due to their ease of clinical application. ${ }^{3,4}$ Therefore, the importance of color stability in GIC is parallel to the increase in esthetic expectation. In paediatric dentistry, long-term color stability should not only be considered for aesthetic reasons and loss of 
money from repeated restorative procedures but also for the fact that more frequent visits to dentist might cause dental anxiety and behavior management problems among children. ${ }^{2}$

In recent years, the consumption of soft drinks significantly increased among children and youth. Especially flavors such as chocolate, banana, and strawberry added to milk encourage consumption. ${ }^{21}$ Although there are studies in the literature about the coloration of dental materials in different solutions ${ }^{3,6,8,10,21,22}$, studies evaluating the effects of surface coating application on the color stability of GICs is still limited. ${ }^{23,24}$ The present study was designed since there was no study evaluating the effect of surface coating application on the color stability of GICs, which are the materials widely used in dental treatments of children, after exposure to beverages commonly consumed by children.

The immersion time used in the present study was designed by taking reference from the study of Guler et $a l^{22}$ In their study, authors assumed the average consumption duration of a beverage to be 15 minutes and average daily consumption to be 3.2 cups. Thus, 1-day immersion simulates the amount of beverage consumed in approximately 1 month. In this study, color change values at t1 $\left(0^{\text {th }}-1^{\text {st }}\right.$ day $)$ and $\mathrm{t} 2\left(1^{\text {st }}-7^{\text {th }}\right.$ day $)$ were compared. Thus, it was aimed to evaluate the short and long term effect of coating on the color change of GICs.

In the present study Riva Coat was chosen as a coating material. Because two GIC materials (RLC and RSC) were produced by the Riva Coat's manufacturer and there was no study evaluating the efficiency of Riva Coat surface coating resin material on GICs in the literature.

In this study, the color changes were measured using a spectrophotometer. When the literature was examined, CIE Lab was generally used to detect discoloration of restorative materials stored in various beverages. However, the International Commission on Illumination has developed the CIEDE2000 formula, which is more accurate in terms of perceptibility and acceptability due to the inadequacy of the CIE
Lab formula. ${ }^{25}$ The CIEDE2000 formula was also used in this study, as it proved to be more up-todate and appropriate for detecting color changes. ${ }^{26}$

Differences in composition and setting of GICs may affect their staining susceptibility. ${ }^{27}$ The water content of GICs is an also important determinant for color stability. ${ }^{8}$ Compared to RMGICs, GICs contain more water, therefore their water absorption capacity is reduced, resulting in less staining. ${ }^{23}$ When $\mathrm{t} 1$ and $\mathrm{t} 2$ time periods were compared, there was no significant differences in $\Delta \mathrm{E}_{00}$ values of the uncoated RSC, while a statistically significant increase was observed in the $\Delta \mathrm{E}_{00}$ value when the RSC was coated. In RLC, $\Delta \mathrm{E}_{00}$ values showed a significant decrease after the $1^{\text {st }}$ day when uncoated but a significant increase was obtained when coated. There are many studies supporting that surface coating resin should be applied on the surface of GICs and RMGICs. ${ }^{24,28}$ But the manufacturer of RLC does not recommend the use of surface coating but it is recommended to not eat anything for a minimum of 1 hour after the material hardens. In this study, one of the materials showing the highest color change was RLC. This result is in parallel with the previous studies reporting that GIC has higher color stability than RMGICs. ${ }^{29}$ Zimmerli et al. ${ }^{30}$ was reported that the surface coatings have the potential of decreasing the surface porosity and they might reduce the color change by protecting the material from external factors but they tend to break up from the surface. This in vitro study was completed within 7 days, simulating approximately 7-month of staining, so no separation from the surface was occurred in the coating material. Using a surface coating is not recommended by the manufacturer of CR but in a previous study, it was stated that coating the $\mathrm{CR}$ enhanced the mechanical properties. ${ }^{31}$ The manufacturer of $\mathrm{Z}$ recommends cocoa butter as a coating material. However, this material can cover the restoration surface for a short time and it may fall short in moisture control. In our study, coating material was also applied on the surfaces of $\mathrm{CR}$ and $\mathrm{Z}$ specimens, included in the RFGICs, and no significant differences were found between the $\Delta \mathrm{E}_{00}$ values of the coated and uncoated specimens at the same 
time interval or within the coated and uncoated specimens at different time intervals. The coated $\mathrm{CR}$ and $\mathrm{Z}$ did not show any significant differences in discoloration when immersed in different immersion solutions in $\mathrm{t} 1$ and $\mathrm{t} 2$. It has been observed that the effects of the solutions on color change are protected with when $\mathrm{CR}$ and $\mathrm{Z}$ were coated. The consumption of acidic drinks is very common among all the adolescent and children. Acidity of these beverages might damage the properties of restorative materials. ${ }^{32}$ In a study evaluating the effect of acidic drinks on bacterial adhesion in GICs, it was reported that cola caused the deterioration of GICs surface layer and consequently, an increase in bacterial adhesion. Even if the use of surface coating material decreased the bacterial adhesion, it caused an increase in bacterial adhesion due to the rapid dissolution of coating material under the acid effect. ${ }^{33}$ In this study, only the color changes of GICs were compared, bacterial adhesion was not evaluated. Among the solutions used in the present study, cola was found that caused in the highest level of color change in coated and uncoated specimens. This might be because it has a lower $\mathrm{pH}$ than other solutions. In addition, cola is a brown carbonated beverage which gains its color by adding caramel that displays colors ranging from pale yellow to deep brown. ${ }^{34}$ Thus, clinicians should warn the patients, who consume cola at high amounts, about the discoloration of GIC-based dental restorations. In this study, $\Delta \mathrm{E}_{00}$ values of specimens in cola in all times were found to be higher than the acceptability threshold. Following cola, chocolate milk was the solution yielding the second-highest color change. Although $\mathrm{pH}$ value of chocolate milk is more alkaline than the other solutions, it is thought that the staining particles in solution might cause discoloration. These results are in parallel with the previous studies stated that the color changes of restorative materials may vary depending on the size of particles in the staining solution and the restorative material's components. ${ }^{35}$

As expected, the lowest color change at $\mathrm{t} 1$ and $\mathrm{t} 2$ was observed in distilled water in all GIC groups. Consequently, it was found that the color change was not related to whether the GICs were coated, but with color change being associated with GIC type and immersion time. Since this study is in-vitro, it cannot fully provide clinical applications. Saliva generally acts as a buffer for $\mathrm{pH}$ of beverage and it dilutes the concentration of beverages in the mouth. However, in this study, the specimens were stored in undiluted beverages for 7 days. Moreover, only limited time effects of the coating were investigated. Given the fact that longer protection is needed in the oral environment, long-term studies are needed. Besides, the absence of previous studies testing similar GICs and methodology together made it difficult for comparison.

\section{CONCLUSIONS}

Within the limitations of present study, all GIC groups exhibited less color stability than other solutions when immersed in cola. RFGICs showed more stability in terms of color change in the long term than other GICs. Determining the role of coatings in the color stability and which GIC material is sensitive to the color changes are very important for in estimating the lifetime of the restoration.

\section{ACKNOWLEDGEMENT}

None to declare.

\section{CONFLICT OF INTEREST}

Author confirm that he has no conflict of interest.

\section{$\ddot{O} Z$}

Amaç: Çalışmanın amacl, cam iyonomer içerikli (CIS) farkl restoratif materyallerde yüzey örtücü uygulamasının, çocukların sıklikla tükettiği içeceklerin renk stabilitesi üzerine etkisini değerlendirmektir. Gereç ve Yöntemler: Bu çalışmada dört farklı CIS ve bir yüzey örtücü kaplama materyali kullanild. Her bir CIS 'den disk şeklinde on alt örnek yapild ve kaplanmamış ve kaplanmış olmak üzere iki gruba ayrıldı ( $n=8)$. Renklenmeleri için örnekler yedi gün boyunca kola, portakal suyu, çikolatal süt ve su solüsyonlarında bekletildi. Renk ölçümleri, solüsyonlarda bekletilmeden önce başlangıçta ve 1. ve 7. günlerin sonunda spektrofotometre kullanilarak yapıld. Renk değişimleri $\left(\Delta E_{00}\right)$, CIEDE2000 formülü kullanilarak hesaplandl. Veriler Kruskall-Wallis ve Wilcoxon testi ile analiz edildi ( $p<0.05)$. Bulgular: Kaplanan ve kaplanmayan tüm CIS'lerde $\Delta E_{00}$ 
değerleri, yedi günlük bekletilme sonrasında tüm solüsyonlarda artış gösterdi. Kolada bekletilen tüm örneklerden elde edilen $\Delta E_{00}$ değerleri, kabul edilebilirlik eşiğinin üzerinde olduğu tespit edildi. Ayn CIS'lerde, ayn zaman dilimlerinde kaplanmiş ve kaplanmamış örnekleri arasında $\Delta E_{00}$ değerleri açısından istatistiksel bir fark bulunamad. Sonuçlar: CIS'lerin kaplanmasl, nispeten iyi bir renk stabilitesi sergiledi ve renklenmeye karşı koruma sağladı. Çocuk diş hekimliğinde CIS içerikli dental materyaller tercih edilirken renklenme etkileri de göz önünde bulundurulmalıdır. Anahtar kelimeler: Yüzey örtücü ajan, cam-iyonomer siman, renklenme.

\section{REFERENCES}

1. Garcia-Godoy F. Resin-based composites and compomers in primary molars. Dent Clin North Am. Jul 2000;44(3):541-570.

2. Iazzetti G, Burgess JO, Gardiner D, Ripps A. Color stability of fluoride-containing restorative materials. Oper Dent. Nov-Dec 2000;25(6):520-525.

3. Mohan M, Shey Z, Vaidyanathan J, Vaidyanathan TK, Munisamy S, Janal M. Color changes of restorative materials exposed in vitro to cola beverage. Pediatr Dent. Jul-Aug 2008;30(4):309-316.

4. Francci C, Deaton TG, Arnold RR, Swift EJ, Jr., Perdigao J, Bawden JW. Fluoride release from restorative materials and its effects on dentin demineralization. J Dent Res. Oct 1999;78(10):16471654.

5. Baig MS, Fleming GJ. Conventional glass-ionomer materials: A review of the developments in glass powder, polyacid liquid and the strategies of reinforcement. J Dent. Aug 2015;43(8):897-912.

6. Gonulol N, Ozer S, Sen Tunc E. Water Sorption, Solubility, and Color Stability of Giomer Restoratives. J Esthet Restor Dent. Sep-Oct 2015;27(5):300-306.

7. Bayne S, Thompson G, D T. Dental Materials. In: Roberson TM, Heyman HO, EJ S, eds. Sturdevant's art \& science of operative dentistry. 4th ed. Mosby; 2002:135-234.

8. Bagheri R, Burrow MF, Tyas M. Influence of foodsimulating solutions and surface finish on susceptibility to staining of aesthetic restorative materials. J Dent. May 2005;33(5):389-398.
9. Dietschi D, Campanile G, Holz J, Meyer JM. Comparison of the color stability of ten new-generation composites: an in vitro study. Dent Mater. Nov 1994;10(6):353-362.

10. Al Kheraif AA, Qasim SS, Ramakrishnaiah R, Ihtesham ur R. Effect of different beverages on the color stability and degree of conversion of nano and microhybrid composites. Dent Mater $J$. 2013;32(2):326-331.

11. Friedl K, Hiller KA, Friedl KH. Clinical performance of a new glass ionomer based restoration system: a retrospective cohort study. Dent Mater. Oct 2011;27(10):1031-1037.

12. Bagheri R, Taha NA, Azar MR, Burrow MF. Effect of G-Coat Plus on the mechanical properties of glassionomer cements. Aust Dent J. Dec 2013;58(4):448453.

13. Bonifácio CC, Werner A, Kleverlaan CJ. Coating glass-ionomer cements with a nanofilled resin. Acta Odontol Scand. Dec 2012;70(6):471-477.

14. Lohbauer U, Kramer N, Siedschlag G, et al. Strength and wear resistance of a dental glass-ionomer cement with a novel nanofilled resin coating. Am J Dent. Apr 2011;24(2):124-128.

15. Cortopassi LS, Shimokawa CAK, Willers AE, Sobral MAP. Surface roughness and color stability of surface sealants and adhesive systems applied over a resin-based composite. Journal of Esthetic and Restorative Dentistry. 2020;32(1):64-72.

16. Muhittin U, Burak TU, Kam HO. Color Stability of Microhybrid and Nanofilled Composite Resins: Effect of Surface Sealant Agents Containing Different Filler Content. J Contemp Dent Pract. Sep 1 2019;20(9):1045-1050.

17. Manabe A, Kato Y, Finger WJ, Kanehira M, Komatsu M. Discoloration of coating resins exposed to staining solutions in vitro. Dent Mater J. May 2009;28(3):338-343.

18. Xing W, Jiang T, Liang S, et al. Effect of in-office bleaching agents on the color changes of stained ceromers and direct composite resins. Acta Odontol Scand. Nov 2014;72(8):1032-1038.

19. Sharma G, Wu W, Dalal EN. The CIEDE2000 color-difference formula: Implementation notes, 
supplementary test data, and mathematical observations. Color Research \& Application. 2005;30(1):21-30.

20. Paravina RD, Ghinea R, Herrera LJ, et al. Color difference thresholds in dentistry. J Esthet Restor Dent. Mar-Apr 2015;27 Suppl 1:S1-9.

21. Tunc ES, Bayrak S, Guler AU, Tuloglu N. The effects of children's drinks on the color stability of various restorative materials. J Clin Pediatr Dent. Winter 2009;34(2):147-150.

22. Guler AU, Yilmaz F, Kulunk T, Guler E, Kurt S. Effects of different drinks on stainability of resin composite provisional restorative materials. J Prosthet Dent. Aug 2005;94(2):118-124.

23. Jafarpour D, Mese A, Ferooz M, Bagheri R. The effects of nanofilled resin-based coatings on the physical properties of glass ionomer cement restorative materials. J Dent. Oct 2019;89:103177.

24. Hotta M, Hirukawa H, Yamamoto K. Effect of coating materials on restorative glass-ionomer cement surface. Oper Dent. Mar-Apr 1992;17(2):57-61.

25. Herrera LJ, Pulgar R, Santana J, et al. Prediction of color change after tooth bleaching using fuzzy logic for Vita Classical shades identification. Appl Opt. Jan 20 2010;49(3):422-429.

26. Ghinea R, Pérez MM, Herrera LJ, Rivas MJ, Yebra A, Paravina RD. Color difference thresholds in dental ceramics. J Dent. 2010;38 Suppl 2:e57-64.

27. Ayad NM. Susceptibility of restorative materials to staining by common beverages: an in vitro study. Eur $J$ Esthet Dent. Summer 2007;2(2):236-247.
28. Ribeiro AP, Serra MC, Paulillo LA, Rodrigues Junior AL. Effectiveness of surface protection for resin-modified glass-ionomer materials. Quintessence Int. Jun 1999;30(6):427-431.

29. Sidhu SK. Clinical evaluations of resin-modified glass-ionomer restorations. Dent Mater. Jan 2010;26(1):7-12.

30.Zimmerli B, Koch $T$, Flury S, Lussi A. The influence of toothbrushing and coffee staining on different composite surface coatings. Clin Oral Investig. Apr 2012;16(2):469-479.

31.Zoergiebel J, Ilie N. Evaluation of a conventional glass ionomer cement with new zinc formulation: effect of coating, aging and storage agents. Clin Oral Investig. Mar 2013;17(2):619-626.

32. Nasim I, Neelakantan P, Sujeer R, Subbarao CV. Color stability of microfilled, microhybrid and nanocomposite resins--an in vitro study. J Dent. 2010;38 Suppl 2:e137-142.

33. Poggio C, Vialba L, Marchioni R, Colombo M, Pietrocola G. Esthetic restorative materials and glass ionomer cements: Influence of acidic drink exposure on bacterial adhesion. Eur $J$ Dent. Apr-Jun 2018;12(2):204-209.

34. Al-Shalan $T$. In vitro staining of nanocomposites exposed to a cola beverage. Pakistan Oral and Dental J. June 2009;29(1):79-84.

35. Khokhar ZA, Razzoog ME, Yaman P. Color stability of restorative resins. Quintessence Int. Sep 1991;22(9):733-737. 